\title{
A case series of pure neural leprosy in patients diagnosed in a specialized center for the control of Hansen's disease in Colombia
}

\author{
Héctor Serrano-Coll1,2, Olinto Mieles ${ }^{3}$, Calixto Escorcia ${ }^{3}$, Amparo Díaz $^{3}$, \\ Camilo Beltrán ${ }^{1}$, Nora Cardona-Castro ${ }^{1,2}$ \\ 1 Línea de Investigación en Lepra, Instituto Colombiano de Medicina Tropical, Facultad de Medicina, \\ Universidad CES, Medellín, Colombia \\ 2 Escuela de Graduados, Universidad CES, Medellín, Colombia \\ 3 Sanatorio de Contratación ESE, Programa Control de Lepra, Contratación, Santander, Colombia
}

Pure neural leprosy, defined as a peripheral neuropathy in which the patient has no skin lesions, is difficult to diagnose. Its verification by bacteriological index and histopathology is not possible in the majority of the patients.

We describe four cases of pure neural leprosy diagnosed by clinical criteria. The clinical outcome of three of the patients after specific treatment was satisfactory, while the other one developed progressive neural damage despite the therapy. All patients were treated in a specialized center for the management and control of Hansen's disease in the municipality of Contratación, Santander, Colombia.

Key words: Leprosy, tuberculoid/diagnosis; therapeutics; case studies; Colombia. doi: https://doi.org/10.7705/biomedica.v38i0.3690

\begin{abstract}
Serie de casos de lepra neural pura en pacientes diagnosticados en un centro especializado en el control de la enfermedad de Hansen en Colombia

La lepra neural pura se presenta como una neuropatía periférica sin presencia de lesiones cutáneas. La verificación del diagnóstico mediante el índice bacilar y la histopatología, no es posible en la mayoría de los pacientes.

Se describen cuatro casos de lepra neural pura diagnosticados por clínica; la evolución de tres de los pacientes que recibieron tratamiento específico fue satisfactoria, en tanto que la otra paciente presentó deterioro progresivo a pesar de las medidas terapéuticas. Todos los pacientes fueron atendidos en un centro especializado en el manejo y control de la enfermedad de Hansen, ubicado en el municipio de Contratación, Santander, Colombia.
\end{abstract}

Palabras clave: lepra tuberculoide/diagnóstico; terapéutica; estudios de casos; Colombia.

doi: https://doi.org/10.7705/biomedica.v38i0.3690

Pure neural leprosy is a clinical form of Hansen's disease that affects peripheral nerves without causing skin lesions in the patient $(1,2)$. Therefore, its diagnosis is challenging due to the subjectivity and complexity of the clinical manifestations (3). Although its prevalence is low (5 to $18 \%$ of all leprosy diagnosis), it may be underestimated because simple, reliable and non-invasive diagnostic tools

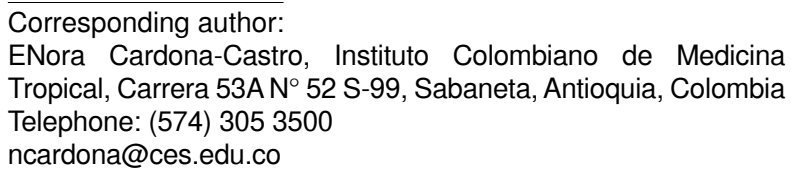

Received: 21/11/16; accepted: 09/08/17 to detect Mycobacterium leprae in patients with this kind of leprosy are currently unavailable. Thus, its detection depends on the clinical experience of the physician $(3,4)$.

The neural condition caused by leprosy results from the asymmetric invasion by $M$. leprae in peripheral nerve fibers, an interaction that causes an inflammatory response at the axon level, resulting in inflammation of peripheral nerve trunks (neuritis) and damaging sensory fibers responsible for exteroceptive sensitivity (5-7). Early pure neural leprosy symptoms occur when infection of the compromised sensory fibers exceeds $30 \%(8)$.

\footnotetext{
Author's contributions:

Olinto Mieles, Calixto Escorcia and Amparo Díaz: Clinical management and diagnosis of the patients Juan Beltrán: Bacilloscopy and serology for Mycobacterium leprae

Héctor Serrano and Nora Cardona-Castro: neurological evaluation, literature review and writing of the article
} 
The diagnosis of the condition is clinical, and it should be suspected in household contacts of patients with Hansen's disease who display only peripheral damage as clinical symptom. Neuropathic symptoms and signs should be a sufficient criterion of diagnosis when additional diagnostic studies are not possible, and when common causes of peripheral neuropathy (e.g. diabetes mellitus, alcoholism and carpal tunnel syndrome) have been ruled out $(1,9)$

While the absence of skin lesions complicates pure neural leprosy diagnosis, detecting $M$. leprae in biopsy smears (skin and peripheral nerve) is also difficult. Given that histopathological findings tend to be nonspecific, implementation of serological tests (such as the detection of IgM antibodies against phenolic glycolipid - I (PLG-I) in patients with peripheral neuropathy may support its diagnosis (10).

We describe here four pure neural leprosy cases diagnosed in the Sanatorium of Contratación in Santander, Colombia.

\section{Case 1}

A 64-year-old male patient exhibiting 2 years of clinical symptoms characterized by muscle weakness in the eyes, hands, and feet with associated sensory loss in these areas.

The patient did not have a pathological, pharmacological, surgical, or history of trauma to explain these symptoms. As regards the epidemiological nexus, the patient's father and paternal uncles were both leprosy patients. In addition, the patient had lived for 20 years with a woman suffering from leprosy. Finally, the patient hunted and ate armadillo.

The physical examination did not reveal skin lesions. A neurological assessment of the face, head, and neck revealed an absence of the bilateral corneal reflex and weakness in the orbicular muscle of the eyelids involving the trigeminal and facial nerve.

We performed a sensitivity evaluation using Semmes-Weinstein monofilaments. In the upper limbs, we observed sensory loss (anesthesia) in areas innervated by the radial median nerve and in the hands, in areas innervated by the ulnar nerve. We also found evidence of a bilateral thickening of the ulnar and right cutaneous radial nerves. We did not observe trophic changes in the hands (figure 1).

In the lower limbs, sensory loss (anesthesia) was evident in both feet in areas innervated by the tibial posterior and fibular common nerves.
During palpation of the nerve trunks, we detected a thickening of both tibial posterior nerves without trophic changes in the feet (figure 1).

As regards laboratory tests, the bacilloscopy of the mucus and interstitial fluid did not detect acid-alcohol resistant bacilli (BAAR). Serology to detect IgG LID1-NOD (cut-off $>0.146$ optical density, OD) was positive (0.480 OD). IgM anti-PGL-1 (cut-off $>0.162$ OD) was negative (0.095 OD). We ruled out damage to the central nervous system (CNS), as computerized axial tomography reported a normal status.

Given the patient's epidemiological nexus, evidence of peripheral neuropathy and the presence of $\lg G$ antibodies against $M$. leprae proteins, we diagnosed the patient with pure neural leprosy.

The patient exhibited grade 1 disability of the eyes, hands, and feet and began multidrug therapy for multibacillary leprosy (MDT-MB). In addition, the patient began physical therapies plus cortico therapy with prednisolone in a descending scheme (60 mg initial doses) and four months later the progression of neural damage stopped.

Table 1 shows the immunological, bacteriological, epidemiological, clinical, and diagnostic characteristics of each of the patients reported in this study.

\section{Case 2}

A 33 year-old male patient exhibiting 3 years of clinical symptoms characterized by muscle weakness in the hands with associated sensory loss in both his hands and feet.

The patient did not have a pathological, pharmacological, surgical, or trauma history to explain these symptoms. Regarding the epidemiological nexus, his father is a leprosy patient. In addition, the patient also hunted and ate armadillo.

Upon physical examination, we did not observe skin lesions. In the neurological assessment of face, head, and neck, we detected that the corneal reflex in the right eye involving the trigeminal nerve was absent.

In the upper limbs, we observed sensory loss (anesthesia) in areas innervated by the median, ulnar and radial nerves in both hands (figure 2) and found evidence of a bilateral thickening of the ulnar nerve and percussing pain in the left median nerve. The Froment test was positive in both hands; we did not observe trophic changes in this area.

In the lower limbs, we found evidence of sensory loss (anesthesia) in areas innervated by the tibial posterior and fibular common nerves in both feet. 


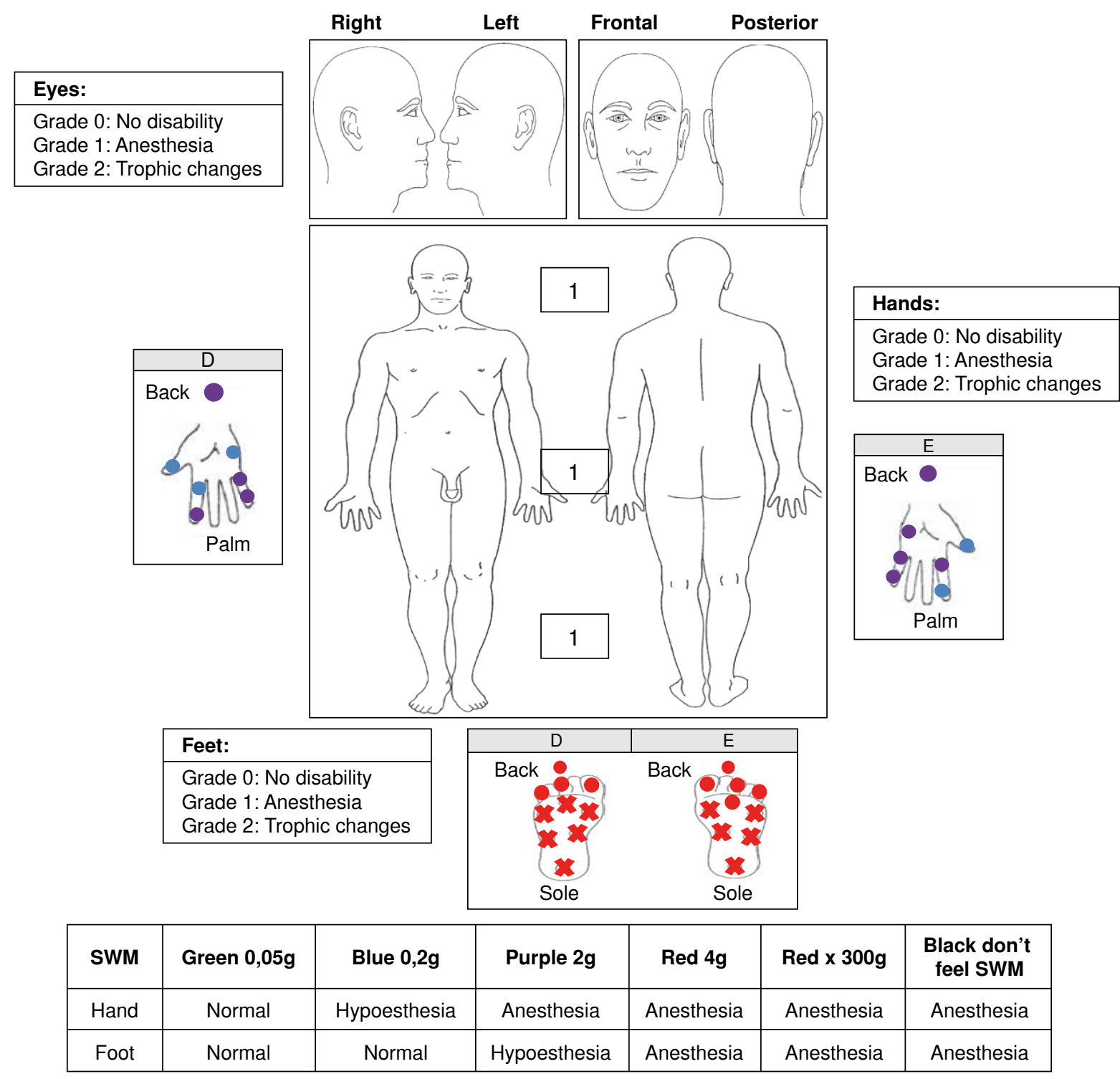

Figure 1. Case 1 findings. SWM: Semmes-Weinsten monofilaments

During palpation of the nerve trunks, we detected a thickening of the right posterior tibial nerve without trophic changes in the feet (figure 2).

The bacilloscopy of the mucus and interstitial fluid did not detect BAAR. Serology to detect lgM against LID 1-NOD (cut-off $>0.153$ OD) was negative (0.072 OD). IgM anti PGL-1 (cut-off>0.162 OD) was negative $(0.081 \mathrm{OD})$.

Considering that this patient had a positive epidemiological nexus with Hansen's disease and an asymmetrical peripheral neuropathy, he was diagnosed with pure neural leprosy with a grade 1 disability (hands/feet) and started MDT-MB with prednisolone in a descending scheme $(50 \mathrm{mg}$ initial doses). Currently, the patient has finished MDT$\mathrm{MB}$ in combination with prednisolone; the clinical outcome was good since the disability grade did not increase (table 1).

\section{Case 3}

A 42-year-old female patient exhibiting 4 years of clinical symptoms characterized by weakness in the hands and lower limbs associated with sensory loss in those areas.

She was initially diagnosed with carpal tunnel syndrome, and received surgical treatment (decompression of the median nerve) in both hands. This diagnosis was established without considering the 
Table 1. Epidemiological, clinical, bacteriological and immunological characterization of the group of patients diagnosed with pure neural leprosy

\begin{tabular}{|c|c|c|c|c|c|c|c|c|}
\hline Patients & $\begin{array}{l}\text { Epidemiological } \\
\text { nexus }\end{array}$ & $\begin{array}{l}\text { Onset of } \\
\text { symptoms }\end{array}$ & $\begin{array}{l}\text { Involvement of } \\
\text { sensitive area }\end{array}$ & $\begin{array}{l}\text { Involvement } \\
\text { of motor area }\end{array}$ & $\begin{array}{l}\text { Nerve trunks } \\
\text { affected }\end{array}$ & $\begin{array}{l}\text { Serological } \\
\text { tests }\end{array}$ & Bacilloscopy & Treatment \\
\hline 1 & $\begin{array}{l}\text { Parents and } \\
\text { paternal uncles with } \\
\text { leprosy Hunting and } \\
\text { consumption } \\
\text { of armadillo }\end{array}$ & 2 years & $\begin{array}{l}\text { Eyes } \\
\text { Hands } \\
\text { Feet }\end{array}$ & $\begin{array}{l}\text { Weakness in } \\
\text { the orbicular } \\
\text { of the eyelids } \\
\text { (facial nerve) }\end{array}$ & $\begin{array}{l}\text { Ulnar nerve } R / L \\
\text { Radial nerve } R \\
\text { Posterior tibial } \\
\text { nerve } R / L\end{array}$ & $\begin{array}{l}\text { *Positive } \\
0,480 \text { OD } \\
\text { ** Negative } \\
0,095 \text { OD }\end{array}$ & Negative & $\begin{array}{l}\text { MDT-MB + } \\
\text { prednisolone }\end{array}$ \\
\hline 2 & $\begin{array}{l}\text { Father with } \\
\text { leprosy } \\
\text { Hunting and } \\
\text { consumption } \\
\text { of armadillo }\end{array}$ & 3 years & $\begin{array}{l}\text { Right eye } \\
\text { Hands } \\
\text { Feet }\end{array}$ & $\begin{array}{l}\text { No trophic } \\
\text { changes }\end{array}$ & $\begin{array}{l}\text { Right and left } \\
\text { ulnar nerves } \\
\text { Left median } \\
\text { nerve } \\
\text { Right posterior } \\
\text { tibial nerve }\end{array}$ & $\begin{array}{l}{ }^{* *} \text { Negative } \\
0,072 \text { OD } \\
{ }^{* *} \text { Negative } \\
0,081 \text { OD }\end{array}$ & Negative & $\begin{array}{l}\text { MDT-MB + } \\
\text { prednisolone }\end{array}$ \\
\hline 3 & $\begin{array}{l}\text { Cousins with leprosy } \\
\text { Consumption } \\
\text { of armadillo }\end{array}$ & 3 years & $\begin{array}{l}\text { Eyes } \\
\text { Hands } \\
\text { Feet }\end{array}$ & $\begin{array}{l}\text { No trophic } \\
\text { changes }\end{array}$ & $\begin{array}{l}\text { No thickening } \\
\text { of nerves }\end{array}$ & $\begin{array}{l}{ }^{*} \text { Negative } \\
0,109 \text { OD } \\
{ }^{* *} \text { Negative } \\
0,096 \text { OD }\end{array}$ & Negative & $\begin{array}{l}\text { MDT-PB + } \\
\text { prednisolone }\end{array}$ \\
\hline 4 & $\begin{array}{l}\text { Grandparents } \\
\text { with leprosy }\end{array}$ & 4 years & Hands & $\begin{array}{l}\text { Left hand, } \\
\text { benediction } \\
\text { hand }\end{array}$ & $\begin{array}{l}\text { Left ulnar } \\
\text { nerve }\end{array}$ & $\begin{array}{l}{ }^{*} \text { Negative } \\
0,111 \text { OD } \\
{ }^{* *} \text { Negative } \\
0,098 \text { OD }\end{array}$ & Negative & $\begin{array}{l}\text { MDT-MB + } \\
\text { prednisolone }\end{array}$ \\
\hline
\end{tabular}

${ }^{*}$ IgG LID1-NOD (cut- off>0.146 OD); ** IgM PGL-1 (cut- off >0.162 OD); *** IgM LID1-NOD (cut-off >0.153 OD); OD: Optical densities

clinical symptoms, which were compatible with multiplex mononeuropathy. The patient did not have a pathological, pharmacological, or trauma history to explain these symptoms.

Regarding the epidemiological nexus, the patient had cousins suffering from leprosy and, besides, she ate armadillo.

During the physical examination, no skin lesions were detected. In the neurological assessment of the face, head, and neck, we observed damage of the trigeminal nerve in both eyes.

In the upper limbs, we observed sensory loss (anesthesia) in both hands associated with areas innervated by the median, ulnar, and radial nerves. We found no evidence of a thickening of the peripheral nerve or of trophic changes in the hands (figure 3).

In the lower limbs, we found evidence of sensory loss (anesthesia) in areas innervated by the tibial posterior and fibular common nerves in both feet, but no evidence of a thickening of the peripheral nerve or trophic changes in the feet (figure 3 ).

With regard to laboratory tests, the bacilloscopy did not detect BAAR. Serology to detect IgG anti-LID 1-NOD (cut-off>0.146 OD) was negative (0.109 $\mathrm{OD}$ ), as well as for IgM anti-PGL-1 (cut-off $>0.162$ OD;0.096 OD).

Considering this patient had a positive epidemiological nexus with Hansen's disease, as well as multiplex mononeuropathy without other possible pathologies to explain a neuropathic condition that differed from leprosy, she was diagnosed with pure neural leprosy and grade 1 disability (eyes/hands/ feet), and MDT for paucibacillary leprosy (PB) was started combined with physical therapy. Currently, the patient has improved her strength in hands and lower limbs and she continues with physical therapy (table 1).

\section{Case 4}

A 42-year-old female patient exhibiting 4 years of clinical symptoms characterized by decreased sensitivity in her hands and a retraction of the fourth and fifth finger of the left hand.

The patient did not have a pathological, pharmacological, surgical, or trauma history to explain these symptoms. As regards the epidemiological nexus, the patient's grandparents had leprosy.

The physical examination did not reveal skin lesions and in the neurological assessment of her face, head, and neck, we did not detect damage in the trigeminal or facial nerve. In her upper limbs, we observed sensory loss (anesthesia) in areas innervated by the median, ulnar, and radial nerves of the left hand, as well as a thickening of the left ulnar nerve. The Froment test was positive for her left hand and she had trophic changes (clawed left hand) (figure 4). In the lower limbs, we did not observe sensory or trophic changes in the feet (figure 4).

The bacilloscopy was negative for BAAR. Serology to detect IgG anti-LID 1-NOD (cut-off>0.146 OD) 

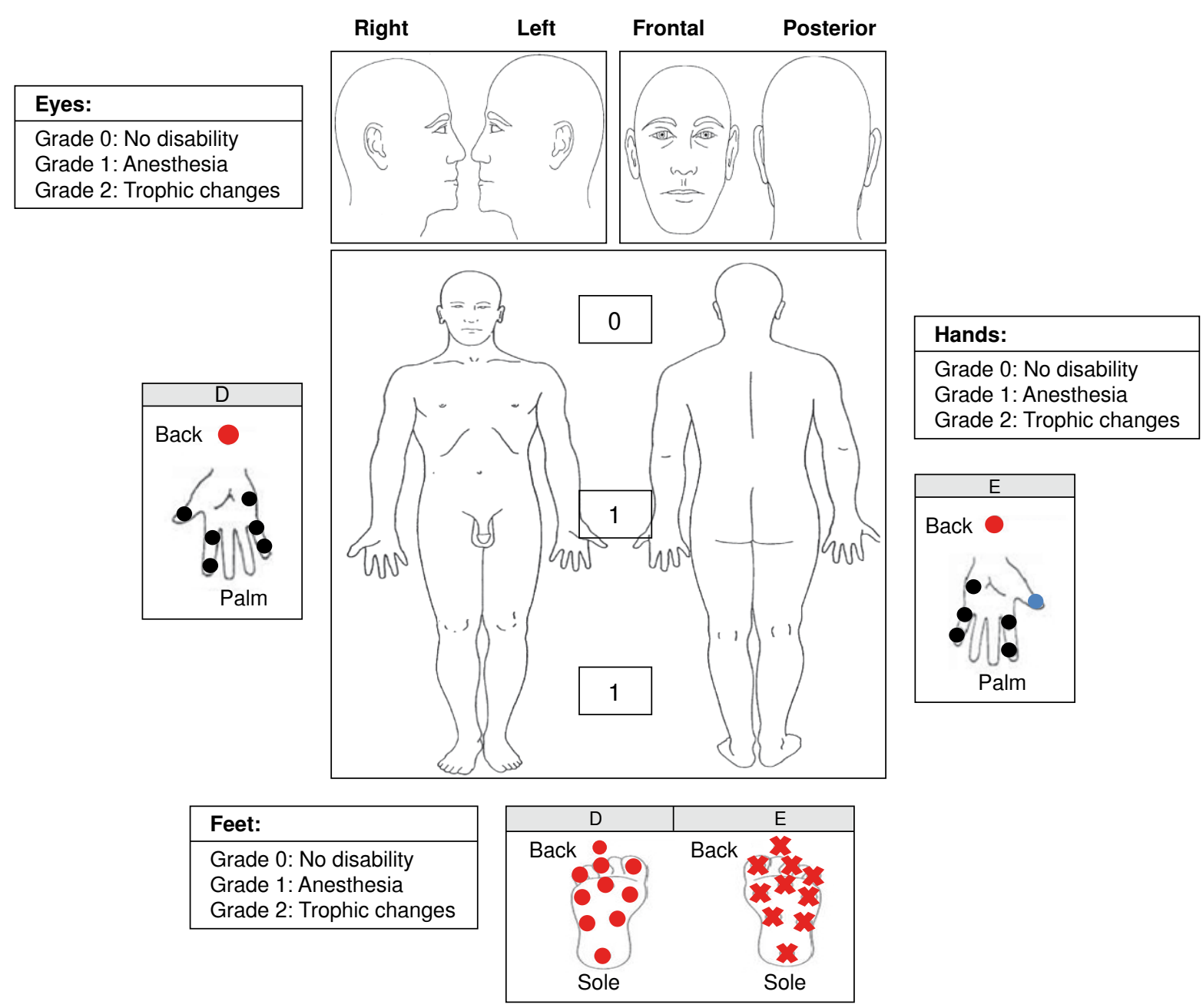

\begin{tabular}{|c|c|c|c|c|c|c|}
\hline SWM & Green 0,05g & Blue 0,2g & Purple 2g & Red 4g & Red $\mathbf{x} \mathbf{3 0 0 g}$ & $\begin{array}{c}\text { Black don't } \\
\text { feel SWM }\end{array}$ \\
\hline Hand & Normal & Hypoesthesia & Anesthesia & Anesthesia & Anesthesia & Anesthesia \\
\hline Foot & Normal & Normal & Hypoesthesia & Anesthesia & Anesthesia & Anesthesia \\
\hline
\end{tabular}

Figure 2. Case 2 findings. SWM: Semmes-Weinsten monofilaments

was negative (0.111 OD), and IgM anti-PGL-1 (cutoff $>0.162$ OD) was also negative (0.098 OD).

Given that the neurological impairment caused a grade 2 disability in her left hand, the patient was diagnosed with pure neural leprosy and began MDT-MB in combination with prednisolone in a descending scheme (40 mg initial doses), as well as physical therapies. Currently, she has received 18 blisters of MDT-MB and she continues with prednisolone and physical therapy. However, despite the treatment, her disability in the left hand is worst because of impairment of the radial nerve (table 1).
Electromyography test was not available for any of these patients.

\section{Discussion}

These cases show that pure neural leprosy represents a diagnostic challenge for healthcare personnel, even for those with extensive expertise, due to the fact that it typically affects the peripheral nervous system (PNS) as a mononeuropathy or multiplex mononeuropathy without causing skin lesions (11). Furthermore, confirming diagnosis by bacteriological and histopathological methods remains difficult, even via neural biopsy, which is 

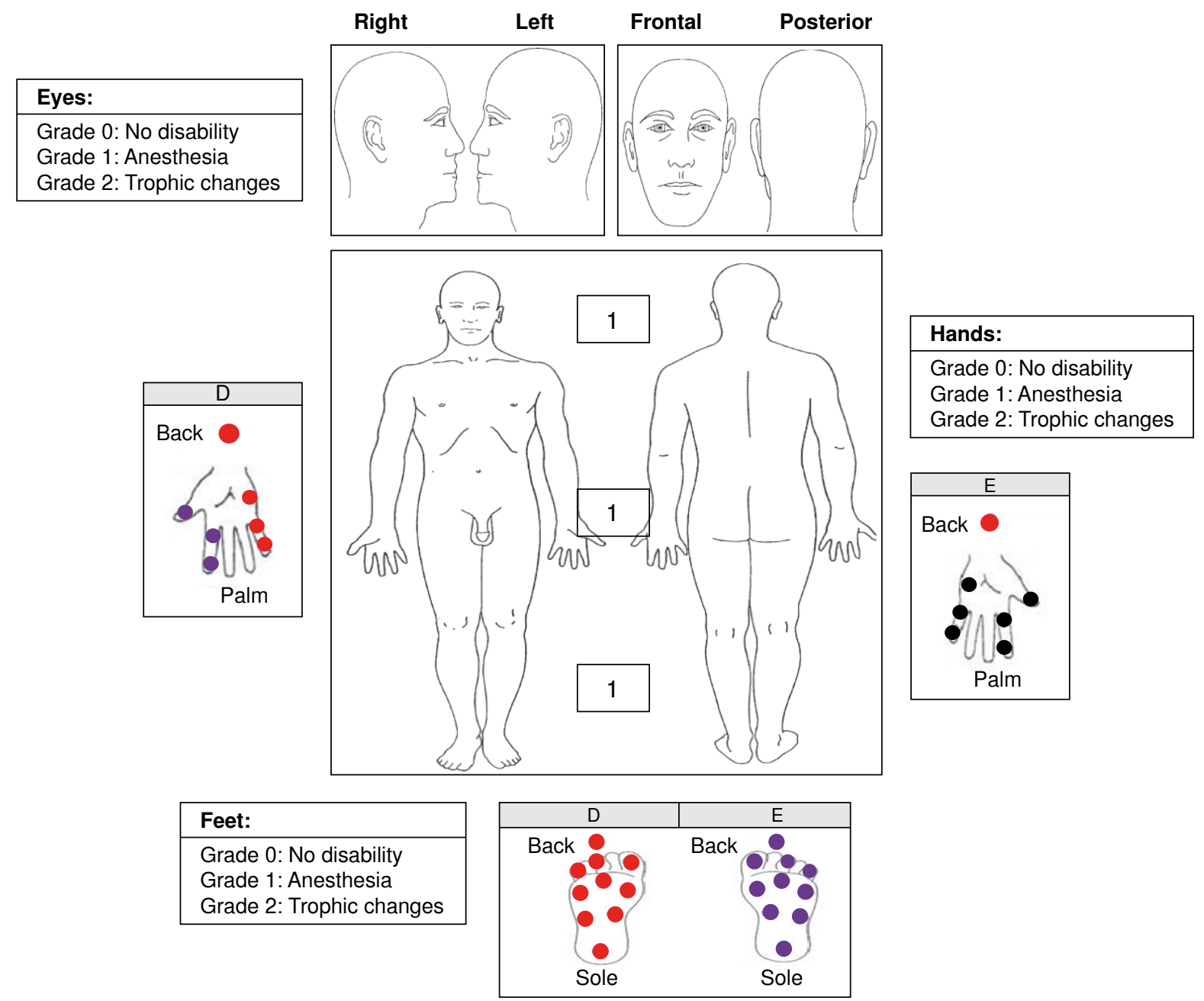

\begin{tabular}{|c|c|c|c|c|c|c|}
\hline SWM & Green 0,05g & Blue 0,2g & Purple 2g & Red 4g & Red x 300g & $\begin{array}{c}\text { Black don't } \\
\text { feel SWM }\end{array}$ \\
\hline Hand & Normal & Hypoesthesia & Anesthesia & Anesthesia & Anesthesia & Anesthesia \\
\hline Foot & Normal & Normal & Hypoesthesia & Anesthesia & Anesthesia & Anesthesia \\
\hline
\end{tabular}

Figure 3. Case 3 findings. SWM: Semmes-Weinsten monofilaments

considered as the gold standard for the diagnosis. The difficulty is primarily explained by the low bacillary load that is typical of this form of leprosy, and the fact that the histopathological changes associated with this condition are also present in other neuropathies, particularly vasculitis, and in chronic inflammatory demyelinating polyneuropathy (CIDP) (12). However, histopathological findings such as endoneural inflammation and epithelioid granulomas in the peripheral nerves of patients with epidemiological nexus and clinical manifestations of neural impairment are the major criteria for the diagnosis of pure neural leprosy (13). Furthermore, the electromyography can be an important tool in the detection of the nerve damage, and to determine the best place to take the biopsy, improving the sensitivity of the histopathology $(1,6)$.

Today, the presence of $M$. leprae may be detected using other diagnostic alternatives, such as polymerase chain reaction (PCR), serological methods to detect antibodies against PGL-I or fine needle aspiration (FNA) cytology (14).

Reja, et al. (4), conducted a study using FNA in 13 patients with pure neural leprosy to demonstrate the presence of $M$. leprae through multiplex PCR 


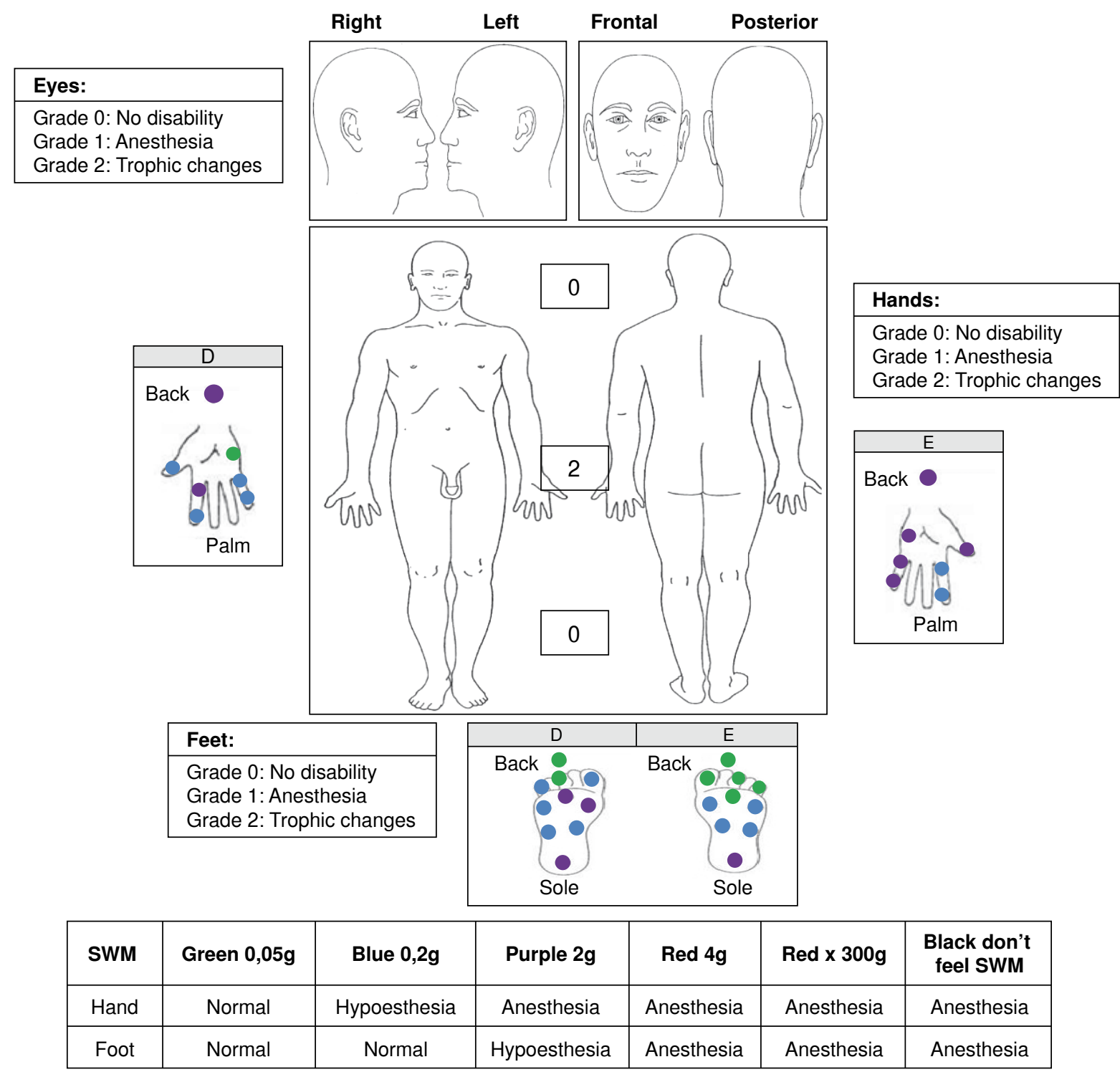

Figure 4. Case 4 findings. SWM: Semmes-Weinsten monofilaments

and Ziehl-Neelsen (ZN) staining. Multiplex PCR detected the presence of mycobacteria in 11 patients $(84.6 \%)$ and $\mathrm{ZN}$ staining showed BAAR in 5 patients (38.4\%). The authors concluded that a combination of multiplex PCR and $\mathrm{ZN}$ staining (from FNA) provided a rapid and reliable diagnosis of the disease (4). Grossi, et al. (15), showed that serology can be useful in detecting and monitoring the disease given that subjects with more than one nerve trunk are four times more likely to be seropositive (15).

The use of serological tests such as PGL-I or NDOLID could also be useful in the detection of pure neural leprosy as positivity of these serological tests is considered a diagnostic criterion for this condition. Moreover, it is important to mention that these tests are positive only in less than $50 \%$ of the patients with pure neural leprosy. Therefore, a negative serological test does not discard its presence (1).

Regarding the personal history of these four cases, it should be mentioned that all of them were both household contacts of patients with Hansen's disease and blood-related. Thus, the patients had a 10 to 14 times more risk of contracting the disease than the general population (16). It is important to note that three of the four patients examined had contact with armadillos, that leprosy is considered a 
zoonotic disease and that they have tested positive for M. leprae in Colombia (17). Truman, et al. (18) confirmed the zoonotic transmission of leprosy: 25 patients with Hansen's disease and 28 armadillos infected with leprosy shared the same $M$. leprae strain (18). Therefore, in patients with peripheral neuropathy of unknown etiology, it is important that physicians inquire about the personal history of their leprosy patients and whether there has been contact with animals that might be related to the transmission of the disease $(16,19,20)$.

The classification of pure neural leprosy is usually paucibacillary (PB) (17), although Rodríguez, et al. (1), have recommended to consider the number of peripheral nerve trunks affected to begin the treatment: patients with two or more affected peripheral nerve trunks should start MDT-MB for 12 months (1). Furthermore, patients can improve their neurological condition using steroids such as prednisolone in 40 to $60 \mathrm{mg}$ doses. However, Smith, et al. (21), observed that the use of prednisolone in $20 \mathrm{mg}$ doses had similar effects to avoid the impairment of nerves in leprosy patients.

In conclusion, pure neural leprosy is an enigmatic and often silent entity that primarily affects household contacts of Hansen's disease patients and its diagnosis is clinical. The disease is often disregarded for the differential diagnosis of possible peripheral neuropathy. It is, therefore, imperative that the medical personnel include it in their diagnostic possibilities.

Finally, it is necessary to continue working on reliable, non-invasive diagnostic techniques, possibly through a combination of serological and genomic tools. The combined use of these tests and of medical devices for the early detection of peripheral neuropathy would facilitate the early diagnosis of pure neural leprosy and mitigate the progression of disabilities caused by neural damage.

\section{Conflicts of interest}

The authors have no conflicts of interest to declare.

\section{Funding}

Colciencias Grant code: 325656933516

\section{References}

1. Rodríguez G, Pinto R. Lepra neural primaria: definición y criterios de manejo. Rev Asoc Colomb Dermatol. 2010; 18:91-5.

2. Payne R, Baccon J, Dossett J, Scollard D, Byler D, Patel $A$, et al. Pure neuritic leprosy presenting as ulnar nerve neuropathy: A case report of electrodiagnostic, radiographic, and histopathological findings. J Neurosurg. 2015;123:123843. https://doi.org/10.3171/2014.9.JNS142210

3. Garbino JA, Marques W, Barreto JA, Heise CO, Rodrigues MM, Antunes SL, et al. Primary neural leprosy: Systematic review. Arq Neuropsiquiatr. 2013;71:397-404. https://doi.org/10.1590/0004-282X20130046

4. Reja AH, De A, Biswas S, Chattopadhyay A, Chatterjee G, Bhattacharya B, et al. Use of fine needle aspirate from peripheral nerves of pure-neural leprosy for cytology and PCR to confirm the diagnosis: A pilot study. Indian J Dermatol Venereol Leprol. 2013;79:789-94. https://doi. org/10.4103/0378-6323.120731

5. Sharma R, Lahiri R, Scollard DM, Pena M, Williams DL, Adams LB, et al. The armadillo: A model for the neuropathy of leprosy and potentially other neurodegenerative diseases. Dis Model Mech. 2013;6:19-24. https://doi.org/10. 1242/dmm.010215

6. Nascimento OJ. Leprosy neuropathy: Clinical presentations. Arq Neuropsiquiatr. 2013;71:661-6. https://doi.org/10. 1590/0004-282X20130146

7. Chacha JJ, Sotto MN, Peters L, Lourenço S, Rivitti EA, Melnikov P. Peripheral nervous system and grounds for the neural insult in leprosy. An Bras Dermatol. 2009;84:495500. https://doi.org/10.1590/S0365-05962009000500008

8. Rodríguez G, Pinto R, Gómez Y, Rengifo ML, Estrada OL, Sarmiento M, et al. Pure neuritic leprosy in patients from a high endemic region of Colombia. Lepr Rev. 2013;84:41-50.

9. Jardim MR, Antunes SL, Santos AR, Nascimento OJ, Nery JA, Sales AM, et al. Criteria for diagnosis of pure neural leprosy. J Neurol. 2003;250:806-9. https://doi.org/10. 1007/s00415-003-1081-5

10. Jardim MR, Antunes SL, Simons B, Wildenbeest JG, Nery JA, Illarramendi $X$, et al. Role of PGL-I antibody detection in the diagnosis of pure neural leprosy. Lepr Rev. 2005;76:232-40.

11. Sehgal VN, Sardana KS. "Intriguing» repercussions of primary neuritic leprosy during the evolution of leprosy across the leprosy spectrum. Int J Dermatol. 2006;45:11213. https://doi.org/10.1111/j.1365-4632.2006.02882.x

12. Hui M, Uppin MS, Challa S, Meena AK, Kaul S. Pure neuritic leprosy: Resolving diagnostic issues in acid fast bacilli (AFB)-negative nerve biopsies: A single centre experience from South India. Ann Indian Acad Neurol. 2015;18: 292-7. https://doi.org/10.4103/0972-2327.162284

13. Antunes SL, Chimelli L, Jardim MR, Vital RT, Nery JA, Corte-Real S, et al. Histopathological examination of nerve samples from pure neural leprosy patients: Obtaining maximum information to improve diagnostic efficiency. Mem Inst Oswaldo Cruz. 2012;107:246-53. https://doi.org/10. 1590/S0074-02762012000200015

14. Theuvenet WJ, Miyazaki N, Roche P, Shrestha I. Cytological needle aspiration of the nerve for the diagnosis of pure neural leprosy. Int $\mathrm{J}$ Lepr Other Mycobact Dis. 1993;61:597-9.

15. Grossi MA, Leboeuf MA, Andrade AR, Bührer-Sékula S, Antunes CM. Risk factors for ML Flow seropositivity in leprosy patients. Rev Soc Bras Med Trop. 2008;41(Suppl.2): 39-44. https://doi.org/10.1590/S0037-86822008000700009 
16. Ministerio de Salud y Protección Social. Guía de Atención Integral de la Lepra. 2012. Fecha de consulta: 23 de abril de 2016. Disponible en: http://www.minsalud.gov. co/Documentos\%20y\%20Publicaciones/GUIA\%20DE\%20 ATENCI\%C3\%93N\%20DE\%20LEPRA.pdf

17. Cardona-Castro N, Beltrán JC, Ortiz A, Vissa V. Detection of Mycobacterium leprae DNA in nine-banded armadillos (Dasypus novemcinctus) from the Andean region of Colombia. Lepr Rev. 2009;80:424-31.

18. Truman RW, Singh P, Sharma R, Busso P, Rougemont $\mathbf{J}$, Paniz-Mondolfi A, et al. Probable zoonotic leprosy in the southern United States. N Engl J Med. 2011;364:1626-33. https://doi.org/10.1056/NEJMoa1010536
19. Talhari S, Garrido N, Oliveira G, Leide M. Hanseníase. $4 .^{\text {a }}$ ed. Manaus: Gráfica Tropical; 2006. p. 216.

20. Clark BM, Murray CK, Horvath LL, Deye GA, Rasnake MS, Longfield RN. Case-control study of armadillo contact and Hansen's disease. Am J Trop Med Hyg. 2008;78:962-7.

21. Smith WC, Anderson AM, Withington SG, van Brakel WH, Croft RP, Nicholls PG, et al. Steroid prophylaxis for prevention of nerve function impairment in leprosy: Randomised placebo controlled trial (TRIPOD 1). BMJ. 2004;328:1459. https://doi.org/10.1136/bmj.38107.645926.AE 